\title{
Influential Factors on Political Participation of Public University Undergraduates in Hebei Province, China
}

\author{
Yanan Yang ${ }^{1,2}$, Nan Xia ${ }^{3}$, Zaid Bin Ahmad ${ }^{1}$, Jayum Anak Jawan ${ }^{1} \&$ Ahmad Tarmizi Talib ${ }^{1}$ \\ ${ }^{1}$ Department of Government and Civilization Studies, Faculty of Human Ecology, Universiti Putra Malaysia, \\ Serdang, Malaysia \\ ${ }^{2}$ Scocial Science Department, Chengde Medical University, Chengde, China \\ ${ }^{3}$ School of International Education, Chengde Medical University, Chengde, China \\ Correspondence: Zaid Bin Ahmad, Department of Government and Civilization Studies, Faculty of Human \\ Ecology, Universiti Putra Malaysia, Serdang, Selangor, Malaysia. Tel: 60-3-8946-7068. E-mail: \\ zaid_a@upm.edu.my
}

Received: August 27, 2018

doi:10.5539/jpl.v11n4p77
Accepted: September 20, $2018 \quad$ Online Published: November 30, 2018

URL: https://doi.org/10.5539/jpl.v11n4p77

\begin{abstract}
In recent decades, political participation amongst young people has attracted much academic research in established democracies. However, as an understudied area in China especially in Hebei province, political participation of public university undergraduates is in low level. Thus, this article concerns the political participation of public university undergraduates in Hebei province of China. The objective of this article is to identify the influential factors and determine the principal influential factor to students' political participation in the public university of Hebei province. Therefore, 1990 respondents were selected based on the cluster sampling method, the main statistical method for evaluation of research hypotheses is by the PLS-SEM. Findings of this study indicate that political education has neither effect nor relation to political participation, whereas university identity, experience, major integrated undertake directly function on political participation. Moreover, political competence is the most important for students' political participation in the public universities of Hebei province, China. Political value cognitive ability is the most important competence which influences the level of political participation among all involved factors in influencing students' political participation in Hebei public universities according to the results of Importance-Performance Map Analysis (IPMA) and Structural Equation Modeling (SEM). Additionally, the author suggested that in order to improve students' participatory level, enhancing capability of students is a necessary way.
\end{abstract}

Keywords: influential factors, political participation, undergraduates, public universities, Hebei Province

\section{Introduction}

Political participation is the core component in democratic politics and is the essential requirement in the construction of socialism political civilization (W. Gao, 2008). In recent decades, political participation amongst young people has attracted much academic research in established democratic countries. However, it has remained an understudied area in China, especially in Hebei province. The previous researchers have shown that the youth are unlikely to participate in politics (N. Fang, 2011) instead of turning to more direct activities such as voluntary activity. As a socialist republic democratic country, the PRC claims the people take part in politics initiative, especially for the youths. Evidence indicates that citizens in people's democratic countries have a low level of political participation (Lu \& Shi, 2015; T. Shi, 1997). The level of political participation gradually decreased year by year (N. Fang, 2011); even the students illustrated the tendency of political apathy (Xing, 2008; $\mathrm{H} . \mathrm{Xu}, 2006)$. There is a lack of research making contributions to students' competence and social-economic background that reflect the trend of Hebei province in China. Young students played as a vanguard role in participating in political events in historical China; however, the youth disengage in the political activities appearing obviously in the modern society. Meantime, as an understudied area in China especially in Hebei province, political participation of public university undergraduates is in low level. Thus, this article concerns the political participation of public university undergraduates in Hebei province of China. The objective of this article is to identify the influential factors and determine the principal influential factor to students' political participation in the public university of Hebei province. 


\section{Material and Methods}

This research is quantitative research, a self-designed questionnaire was based on the systematic literature review, and data was collected from 1990 undergraduates from the public universities of Hebei province in China based on the cluster sampling method and analyzed PLS-SEM by using the SmartPLS of the software. Therefore, five different universities and colleges in Hebei province were chosen. Among the 1990 respondents, the male constituted $36.6 \%$ (728), while the female was $63.4 \%$ (1262). The ratio of female students to male students is $3: 2$, which is corresponded the students' natural ratio (W. Gao, 2008). A majority of the respondents are from the countryside (51.4\%), followed by those hometowns from the city $(25.2 \%)$ and town (23.5\%). The largest group with 1022 respondents is from the countryside, which almost equals the respondents from city plus town group. The frequencies of the respondents are from academic majors including art, science, engineer, and medical and the four groups take up the percentage are similar, the social science group has $510(25.6 \%)$, the science group has 425 (21.5\%), the students in engineer major has 530 (26.6\%), and the medical group has 525 (26.4\%). In summary, 1190 respondents are chosen to analyze political participation representing the level of Hebei province through classifying into varieties of groups by purposeful requirement.

Meantime, the importance-performance map analysis (IPMA) provides a chance to identify which factors in this study is most important to influence students' low-level participation in politics. Furthermore, the assessment establishes according to PLS estimates and adds dimensions in order to evaluate the political participation variable's value. The results of IPMA contain index value and latent variable (LV) performance value which indicates latent variables' performance and effect value which presents the importance of construct on political participation.

\section{Results and Discussion}

\subsection{Political Value Cognitive Ability as the Most Important Factor to Participation}

Table 1 displays the result of IPMA, which is used for the extending the findings of the basis PLS-SEM outcomes through the latent variable scores. When the index value of 3.344 and performance value of 58.592, for example, in respect of the latent variable of 'Leadership' that means Leadership variable plays 58.592 on political participation from the range 0 to 100 with the importance value is 0.128 indicates the effect of leadership on political participation in 0.128 level.

Table 1. The result of IPMA on political participation

\begin{tabular}{|c|c|c|c|}
\hline \multirow{3}{*}{ Latent Variable } & \multicolumn{2}{|c|}{ Performance } & \multirow{3}{*}{$\begin{array}{l}\text { Importance } \\
\text { Total Effect of the Latent Variable on "Political } \\
\text { Participation" }\end{array}$} \\
\hline & Index & $\mathrm{LV}$ & \\
\hline & Value & Performance & \\
\hline Leadership & 3.344 & 58.592 & 0.128 \\
\hline Major & 2.999 & 49.967 & 0.185 \\
\hline Political Efficacy & 2.813 & 45.322 & 0.153 \\
\hline Political Education & 3.472 & 61.812 & 0.029 \\
\hline $\begin{array}{l}\text { Political Value Cognitive } \\
\text { Ability }\end{array}$ & 3.950 & 73.759 & -0.343 \\
\hline Political Participation & 2.174 & 29.354 & Target Construct \\
\hline University Experience & 3.349 & 58.726 & 0.177 \\
\hline University Identity & 3.394 & 59.846 & 0.057 \\
\hline University Involvement & 3.503 & 62.569 & -0.006 \\
\hline
\end{tabular}

The performance value of the target construct "political participation" is 29.354 in the 0 to 100 scale, which is merely close to $30 \%$ of the whole that verifies again the conclusion stated that the level of students' political participation is in low. These additional results of the performance of influential factors serve as a foundation for getting ready for the priority map. Figure 1 visualizes the "Importance level" of each latent variable with its impact on political participation variable. Competence-behavior oriented results are easy to recognize from this graphical representation. If the index value of "political value cognitive ability" increases by one unit, the 
political participation should decrease by 0.343 in a ceteris paribus assessment of results.

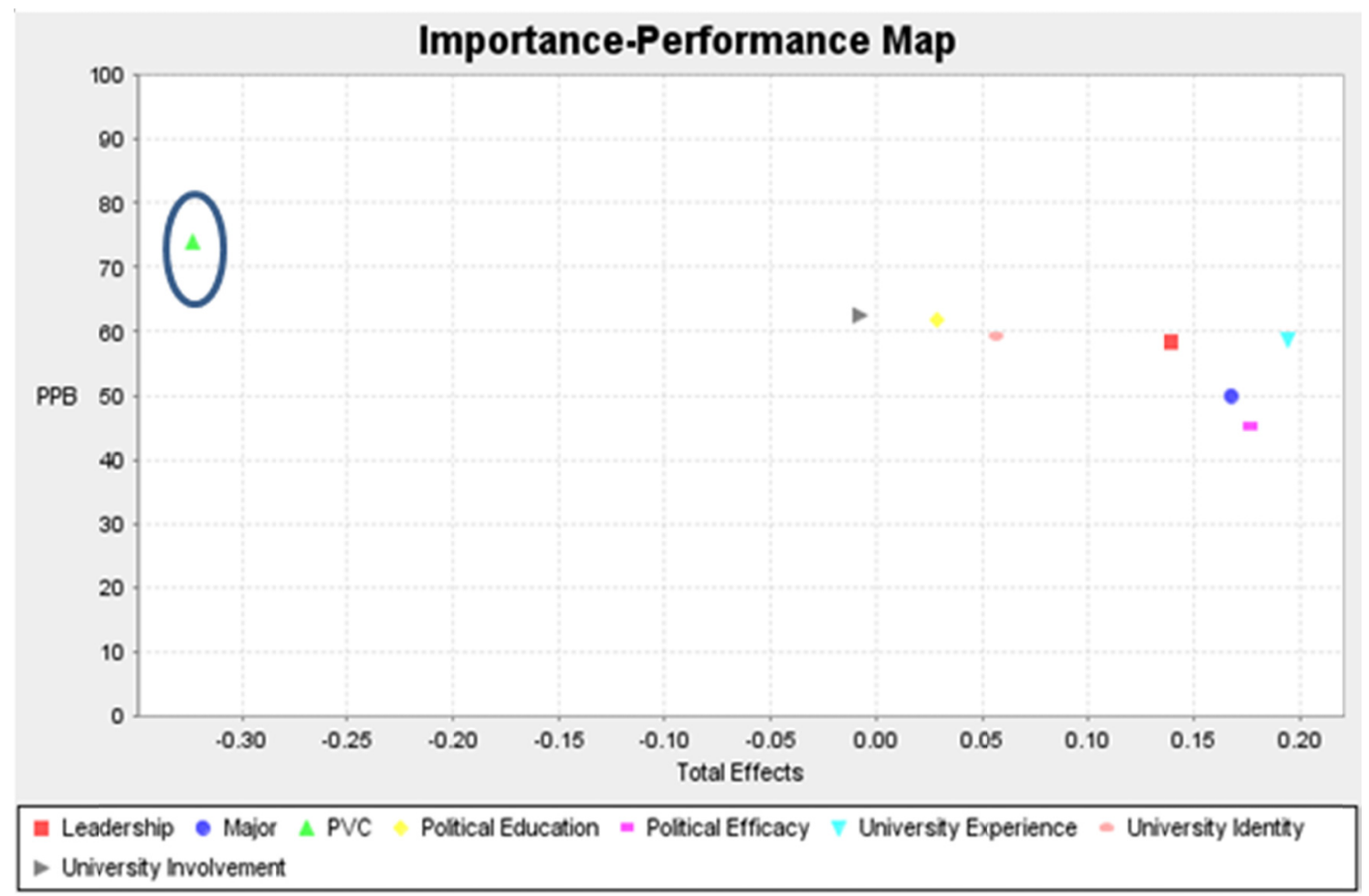

Figure 1. The result of importance-performance map analysis for political participation

It can be seen from table 1 that voting is a direct political activity which impact of the citizen on governmental performance. Vote with mean score 2.74 (1-5 scale) is the highest among the eight behaviors which stand in the middle degree. Demonstration (PPB6) belonging to protest behavior is the lowest among the eight activities with the mean statics 1.71 in general, and 1225 (61.6\%) students never played. PPB1, 2, 3 and 4 are attributed to campaign activities (CA) group, and the level tested by mean score displays lower than vote but higher than protest behavior. At last, the political contact behavior contains PPB7 and PPB8, the mean level between the two activities presents long distance, the former one is 2.01, and the latter is 1.84. Except the election is in the middle level, other behaviors are at the low level which is resulted from the statistics hint.

It is evident that assigning priority to competence-oriented measures relative to the results based on Table 1 and Figure 1, the variable of political value cognitive ability is highly relevant for decreasing students' political participation due to its advert effect. However, this area has high index value and effect value so that there is pivotal potential for further reduces.

Compared with the rest factors, the performance of university involvement (62.569) and political education (61.812) displays relative high; however, the effect value is close to 0 which means that the influence on political participation is near to 0 , which is correspondent to the results that university involvement and civic education have no impact on political participation. Striving should be directed increasing the performance level, the effect like major (0.185) and political efficacy (0.153) are similar on political participation, and look like the performance value is 49.967 and 45.322 . Although the index values are close between leadership (58.592) and university identity (59.846), the importance level is further different with leadership (0.128) and the university involvement (0.057), which indicates that the competence is more critical on political participation. The performance value of the university experience is $\mathbf{5 8 . 7 2 6}$ which similar like leadership; however, the important level stands at 0.177 higher than the former one.

The IPMA results from manifest variables' average value in exogenous latent variables' formative measurement models and the relative importance of their total effect on the endogenous latent variable political participation. It is vivid that political value cognitive ability is the most critical driver of political involvement with multi-competence and university influence and will be discussed detailed in the next section. 


\subsection{The Relations between Influential Factors and Political Participation}

The section aims to examine the relations between the influential factors and political participation. It conducts with the specific purposes, firstly, discussing the reasons why the pivotal factor named political value cognitive ability influences students' political participation saliently; secondly, following the participatory democracy theory, exploring why political education cannot affect students' participatory activities which violate the previous study; and thirdly, arguing why university involvement stands in the dilemma, has effect but not outstanding.

This implementation process provides the chance to identify relevant relationships for the proposed PLS-SEM using direct observation, and the model assessment allows the reliability and validity of the PLS-SEM path modeling results. After testing cause-effect relations, IPMA extracts the most important factor in replenishing and extending the results in this research.

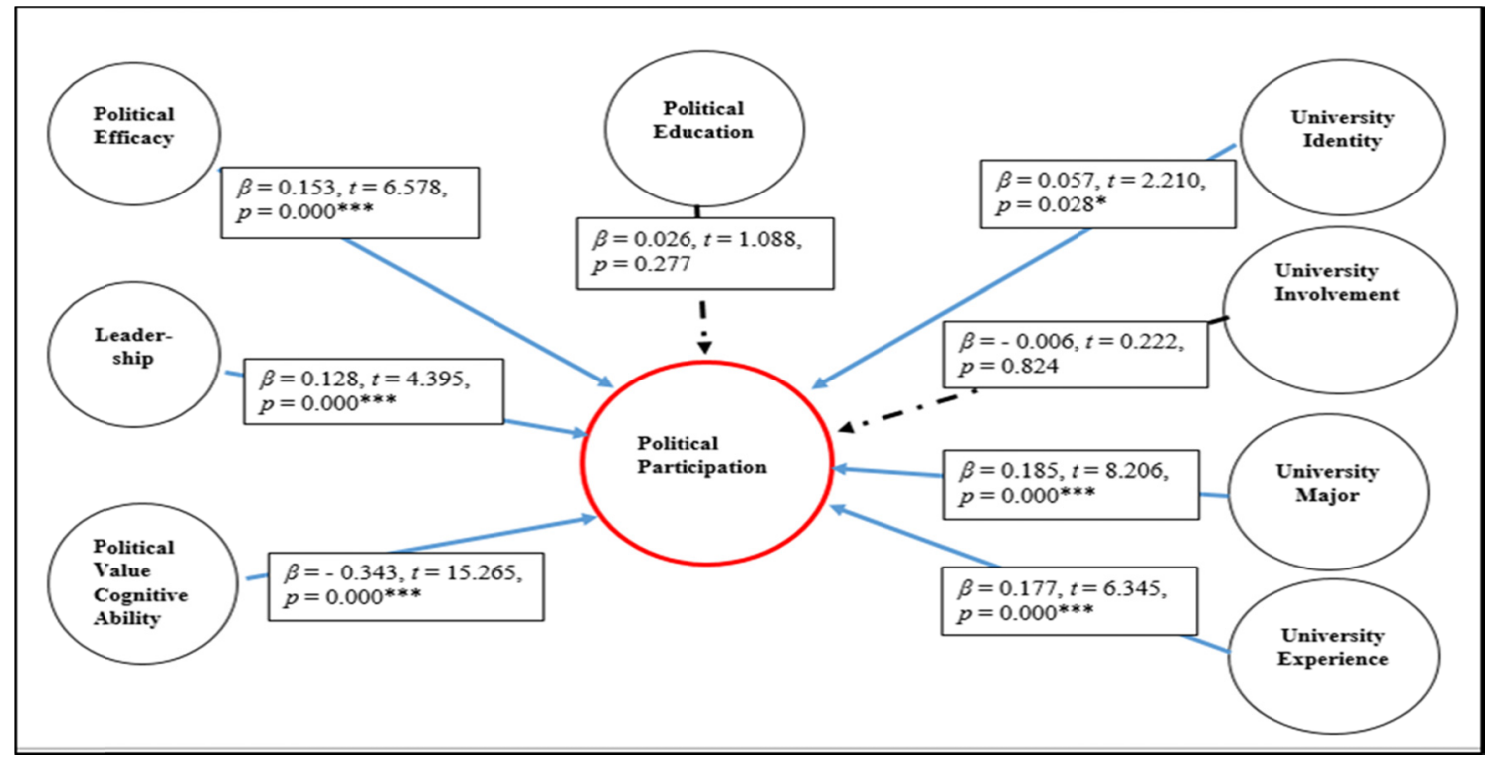

Figure 2. Results between influential factors and political participation

Figure 2 visualized the relationships between influential factors from empirical research and students' political participation; consequently, discussing the elements separated in groups is better for further analysis. Simultaneously, Table 2 is the PLS-SEM results between each influential factors using in this research and political participation, and when $t$ statistics is more than 1.645 , the $p$-value is less than 0.05 that illustrates the significant relationship between the influential factors and political participation.

\subsubsection{Competence}

The competence is made up of political value cognitive ability, political efficacy and leadership. It aims to examine its effect on the students' political participation based on the participatory democracy theory in this research. The cognitive ability is one kind of the political competence assessed in the research. It is citizens' acknowledgment and understanding for the political phenomenon (W. Gao, 2009) and the principal element in recognizing the political system in the cognitive ability (Yang, 2016). Both the IPMA and the PLS-SEM results illustrates the political value cognitive ability has a negative relationship in influencing political participation due to the $\beta=-0.343, t=15.265, p=0.000^{* * *}$.

Table 2. The PLS-SEM results of the relation between influential factors and political participation

\begin{tabular}{lrrrr}
\hline & $\begin{array}{l}\text { Direct Effect } \\
(\beta)\end{array}$ & $\begin{array}{l}\text { Standard } \\
\text { Deviation }\end{array}$ & $t$ Statistics & \multicolumn{2}{c}{$p$ Values } \\
\hline Competence & & & & \\
PVC -> PPBs & -0.343 & 0.022 & 15.265 & $0.000^{* * *}$ \\
IPE -> PPBs & 0.153 & 0.023 & 6.578 & $0.000^{* * *}$ \\
Leadership -> PPBs & 0.128 & 0.029 & 4.395 & $0.000^{* * *}$ \\
\hline
\end{tabular}


The result of the political cognitive ability indicated that the higher ability students have, and the lower level students take part at. It differs from prior research, possibly because the positive relation conducted was used the ability as the independent variable (Taber \& Lodge, 2006; W. Gao, 2009) and as the mediated variable (Vecchione \& Caprara, 2009). Political cognitive ability is the prerequisite and basement of participatory politics (P. Wang, 2006). The requirements of modern democratic politics directly influence the citizens' political emotion and value concept formation (Tao \& Chen, 1998). Cognitive ability is the external manifestation of knowledge, neither have this ability nor considering the effects of behaviors, students attempt to be in politics and enjoy the process which is the mini political society. Oppositely, if students focused and judged the results well and understood the hardships of the process, not participating in or participating in less can maximize benefits because they did not spend time and energy. Students participate widely with a high level is an effective way to strength participatory social communication ability, even improve the level of participation and in future, minimize the gap of inequality.

Political value cognitive ability is the essential competence which influences the level of political participation among all involved factors in influencing students' political participation in Hebei public universities according to the results of IPMA and SEM; therefore, the following reasons contribute to the negative relation to the low-level political participation.

Firstly, the cognitive ability internally leads the students to recognize the reality in the process of action. It helps students to understand the intention of political participation (Eccles \& Allan, 2002). Taking election as an example, whereas the students knew nothing about the candidate initially; they could judge the elected candidate represents the appeal of students or not. Therefore, the voting would not influence the outcome because the candidates will become the representative, even represent students' benefit. Hence, when the students faced the political reality, refusing or seldom participation became the rational choice. The skill leads the students to cognitive the fact and to cause the negative relationship.

Secondly, the high capability provides the basement to evaluate the outcome of participation. Students in university obtain higher education and transform knowledge into practice, level of participation is low but limited practical experience tells students that participating or not has little impact on the outcome, and even the appeals cannot convey to the political candidates, so that the requirements will not achieve or overcome at all. Thence, it is normal to not participate in the sufficient recognition of the results that further explaining why the higher capability students have, the lower participation appears.

The cognitive ability helps the student to understand the political reality in the participatory process and realize the outcome of participation that is why the students' political cognitive ability hurts political participation.

Political efficacy is the subjective evaluation of participatory behaviors' influence (Xiong, 2015; Eckstein, Noack, \& Gniewosz, 2013; Langton \& Karns, 1969). The effective value of political efficacy on political participation is 0.153 means that the stronger political efficacy the individual has, the more ability in evaluating the political issue, further influencing political participation with $\mathrm{t}=6.578, \mathrm{p}=0.000^{* * *}$. Political efficacy as a capability directly influence political participation, the result is similar to other scholars' previous study (Pye \& Verba, 1965; Wheeler, Shanine, Leon, \& Whitman, 2014).

Political efficacy refers to the belief which citizens have and believe have influence on the government (R. Hu, 2015), reflects citizens' ability in understanding and judging politics and perceives the feedback on the perception of government or officials' behavior in the political system (Gallego \& Oberski, 2012b; Gerber et al., 2011). It is a similar result as previous research that the relation is positive between political efficacy and political participation, due to the reasons as follows.

First of all, the political perception of students is worthy of recognition. Students in university accept academic knowledge as soon as learning national guidelines and policies; the knowledge learning process supports students a chance to understand and judge politics and then foster political efficacy. Therefore, the more political efficacy students have, the higher participatory level students stand in.

Second, the political judgment of students is valuable to be affirmed. Attention and discussion and then criticizing the current political issues are the processes of strengthening political efficacy and giving the feedback about governmental and politicians' behaviors. Although the participatory level is low, it does not affect political efficacy play an important function in participation. Consequently, political efficacy has a positive relationship to the low-level political participation of students in the public university of Hebei province.

Leadership is the ability to persuade and lead others to participate in politics (Chan \& Nesbitt-Larking, 1995; DeSouza, 1986; Pattie et al., 2003). It is a critical skill for students to improve the low participatory level 
because of $\beta=0.128, \mathrm{t}=4.395, \mathrm{p}=0.000^{* * *}$. The result is by fruitfully examined the impacts and the relationship between leadership and political participation. Leadership as a political skill in the study has a similar outcome to the previous scholars (Margetts, John, Hale, \& Reissfelder, 2015; Weare, Lichterman, \& Esparza, 2014). It is a correspondent that leadership influences political involvement from the capability perspective.

Leadership in this study is mainly considered from individual competence perspective and the recognized significance of leadership as an important outcome of personality. Substantial research exists examining the impact of leadership on political participation and gain positive relations (Bolkan \& Goodboy, 2009; Dugan et al., 2011; Montoya, Fanta-Hardy, \& Garcia, 2000; Palmer, 2014) without exception in this study; therefore, the reasons addressing in shaping political participation are as follows.

Intuitive ability is in the first place to give impetus for students to political engagement. Students can convince others to participate, and in the same way to explain is that students know how to participate in politics first and motivate colleagues to engage. Taking the initiative in political activities needs capability taken as force power, in order to achieve active participation, so the higher leadership students have and the relative higher participation level keeps, which exists in this study.

Individual request become the second reason that why leadership has an impact on political participation. Not only sharing the suggestions and advice to others but also taking as the leader in group activities, even serving as a model among colleagues, these appeals require the students who have high leadership often step ahead of others in political issues. The process of participation is both shown ability in public issues and practice whether could be a qualified leader or not. Therefore, leadership in this study has a positive relationship because of the intuitive ability and personal request.

Pursuing equality is the third requirement to consider in the leadership. Whereas the Liberal Democrats chose to hind the inequality between the politics and economics, the participatory democrats asserted that the citizens should unite and form a power to resist the disparity. And the powerful union led the public mass to seek the legal solutions in the engagement process (H. Zheng, 2012a). The low-level participation has a high correlation to the social inequality (Macpherson, 1977), no matter the participatory system eliminates the disparity or not. Hence, a relative equal and humane society is the demand for a stronger participatory society. Whether leadership is active or not influences the equality in the social reality. The stronger leader guides the citizens to seek a dynamic community; simultaneously, reflects the personal skill. While eliminating unfairness displays the leadership in the process.

In summary, the students' political competence in this research discussed from the political efficacy, leadership, and political value cognitive ability. The former two variables had a positive relationship, and the latter one was in a negative correlation to political involvement. Political skill contributes most in political participation because it is the same process to strengthen the ability.

\subsubsection{University Education}

Previous research on participatory democracy does pay sufficient attention to the distinct nature of political education with varying experiences of political participation (Pateman, 1970; Verba et al., 1993b; Lu \& Shi, 2015; Syal, 2012); however, the opposite consequence appears because there is no impact of political education on political participation with $\beta=0.029, t=1.088, p=0.277$, and $f^{2}=0.001$. Neither relation nor impact between political education and political participation, due to reasons facing this new phenomenon will be discussed as follows.

Table 3. The PLS-SEM results of the relation between influential factors and political participation

\begin{tabular}{lcccc}
\hline & $\begin{array}{l}\text { Direct Effect } \\
(\beta)\end{array}$ & $\begin{array}{l}\text { Standard } \\
\text { Deviation }\end{array}$ & $t$ Statistics & $p$ Values \\
\hline University Education & \multicolumn{3}{c}{0.026} & 1.088 \\
PE -> PPBs & 0.029 & 0.277 \\
Criteria: $t$ value $>1.645(p$ value $<0.05) ; t$ value $>2.33\left(p\right.$ value $<0.01^{* *}, p$ value $\left.<0.001^{* * *}\right)$ & \\
\hline
\end{tabular}

Different from the former study of the precursory scholars has claimed that education promotes greater political participation (Kam \& Palmer, 2011; Mayer, 2011; C. Gao, 2010), and the opponent investigated the negative 
significance correlated between vote and political education (L. Zheng \& Zhu, 2013); otherwise, there is no cause-effect relation (two-tailed) between political education and political participation in this research. The ITPC should play an essential role in education, guidance and shaping students' ability of political participation; however, it is in an embarrassing situation because of no function on political participation in this research, due to reasons are as follows:

The gap between the educational content and real political life contributes to the first reason. The content of the ITPC is based on the stage and pertinence of educational achievements and the diversity, complexity and mobility of educational respondents' moral conditions. It is a complex system including ideology, political and moral education, "Ideological education is fundamental, political education is the dominant and moral education is the foundation" (Z. Yuan, 2011). The ITPC or political education serves for political and economic governance of the ruling class, so ideology political education must insist on the right political orientation that is the dominant requirement. However, the disconnect between the ITPC content and reality makes the students keep away from political activities because of the boring, flat and unilateral contents of the ITPC. The theoretical political knowledge in the ITPC is politicized, theorized and idealized, which neglects the connection to a social situation, whereas the focus on the political value and moral education and ignore the other wealth. Consequently, the gap weakens students' political participation and gradually becomes the "oral politics" and lack of effectiveness.

The incompatibility between students' subjectivity and spoon-feeding pedagogy can be ascribed to the second reason. A suitable teaching method relates to comprehend and master political knowledge; the traditional single way educational pedagogy loses the practicality. With the rapid development of the economy, society and technology, more and more channels provide the opportunity for the students to obtain knowledge, news or latest information that enhance the students' subjectivity and develop the moral diversity. One-way teaching method makes the unbalance between the educator and the students, even arises the antagonistic sentiments, which is bad for fostering students' political activism. Students are with more knowledge, independence and choice; however, traditional educational method restricts the participatory space. Therefore, the spoon-feeding pedagogy hinders subjectivity of students in the process of education.

Educators' lack of personal and academic charm becomes the third reason. The spirit of Document No. 16th of the central CPC in the "Opinions on Further Strengthening and Improving Ideological and Political Education for College Students" stated that "college educators with good ideas, ethics and personality influence students subtly by taking a highly responsible attitude and being the lead in setting examples, words and deeds. Moreover, the students strengthen their ideology and increase political awareness in the process of mastering the professional knowledge" (Ministry of Education of PRC, 2015).

Simultaneously, the students' quality reflects educators' professional characteristics directly, in short, the charming educator is critical in the process of students' political participation, even each aspect of daily life. With the development and diversity of social-economic components, organizational forms, employment types, and beneficial allocation, some college educators take on the status like political belief and position unsteadiness, political orientation and disciplines ambiguous, political sensitivity and discriminability weakness which generates to mismatch of political concept and behaviors. Losing political personality charming brings about lack of educational impact. The behaviors or attitudes containing scripted, whitewash and no allegiance in the educational process, and misunderstanding the develop line, guiding principle and policy of the PRC in knowledge replenishment process and short of innovation in the practical process directly or indirectly influence students' participation and educators' academic level. Thus, it can be seen that educators' quality in both personal and academic affects students' political activism potentially by the driving force from the educators in university. Therefore, lacks of political and personal charm weaken academic degree and affect students' political participation profoundly.

In short, political education has no relationship and impact on political participation in this research, mainly because of the China's political environment and reality.

\subsubsection{University Community}

University is one of the educational institutions and aims to achieve the purpose of education, which is to teach the student to think of himself (Mezey, 1975). A university is the study place for students during the academic period, which is similar to the workers working in the workplace. It is the intensive community, which supported by her proposition "the workplace to show that participatory democracy was feasible" (Pateman, 1970a, 2012). To examine the external elements concerning is to affect the students' political participation, this study mainly tests from the university category. 
Table 4. The PLS-SEM results of the relation between influential factors and political participation

\begin{tabular}{|c|c|c|c|c|}
\hline & Direct Effect $(\beta)$ & Standard Deviation & $t$ Statistics & $p$ Values \\
\hline \multicolumn{5}{|c|}{ University Community } \\
\hline Major -> PPBs & 0.185 & 0.023 & 8.206 & $0.000^{* * *}$ \\
\hline OI -> PPBs & 0.057 & 0.026 & 2.210 & $0.028 *$ \\
\hline UI -> PPBs & -0.006 & 0.027 & 0.222 & 0.824 \\
\hline UE -> PPBs & 0.177 & 0.028 & 6.345 & $0.000^{* * *}$ \\
\hline
\end{tabular}

\subsubsection{University Experience}

University experience in this research is from the perspective of the practice of political participation. The practical experience mainly includes contacting political leaders through university, the election in university, campaign activities which can help understand the content and process of political participation in the participatory process. Experience promotes students to engage in politics (Shen, Lei, \& Zhou, 2006; H. Zhang \& Wang, 2011; Z. Zhao \& Tang, 2008); university experience has a positive relationship (two-tailed) to political participation with $\beta=0.177, t=6.345, p=0.000^{* * *}$ in this research, which is similar to the previous study. It is obvious to illustrate that university experience has not only impact but also the relationship to political participation and the tendency is positive, and the reasons can be attributed as follows.

Political participation is a kind of political practices which helps the student genuinely cognitive political reality and then improves political participation, because "All is but lip-wisdom that wants experience." Once in the five-year election for undergraduates is seldom, some of the students may be in the four-year university life miss the voting year, under this circumstance, university experience provides a different way to practice participation. In the practical process, students gradually experience the policy-making process and learn more about the political system of China through university experience, the more thought the students have, the better political participation level exists; hence, the relationship between university experience and political participation is positive (two-tailed).

Practice is a test method which is salutary for students to have a better understanding of political participation. University experience provides the chance to fulfill participation, including political contacting, expressing, and discussing politics; the effect of political participation is insufficiently proved in the practice process, eventuating to result ultimately in the low-level participation. The student knew the outcome in the practice so that when participating in politics in real participation, the students become political apathy in the participatory process. Whether effectiveness or not comes to be a norm for students to decide to do or not, which is tested by university experience, so it is not peculiar to appear this result.

\subsubsection{University Community}

The influential factor major identity is mainly discussed the students' ideology about major integrated with the university. Through asking students' opinions about the major integration influences the political involvement, the result indicates that major has a positive relationship to political participation $(\beta=0.185, t=8.206, p=$ $0.000^{* * *}$ ). Students in this research have belongingness to the university where the student studied in and university identity positively promote to participate in politics because of $\beta=0.057, t=2.210, p=0.028^{*}$. The impact of university identity is lower than the major integration, but it is better than university involvement which has no relationship and effect to political participation with $\beta=-0.006, t=0.227, p=0.824$, which indicates the university involvement cannot influence students' political participation in Hebei province, China.

The main result in university environment group is university involvement has neither impact nor relation to political participation, which violates the priori study (Pateman, 1970, 1986; J. E. Leighley, 1995; Thomas et al., 2012a); the reasons can be attributed into the following points.

It is the time to turn to the question of the extent of involvement of students in the students' self-management in university. Students manage behaviors and as well as would like to involvement into university, and make better belongingness to influence university; however, the university involvement has no relationship to political participation. Students manage self-development to be a better person for the university, but the change for political participation is helpless.

Attention policy and working hard in making a difference in order to hope the university has a brilliant future; 
however, the types of focusing on policy and issues related to the university are several ways, after all, the gap between policy implementation and reality exists distance. In China's political system, the NPC formulates the policy, and the common public is the executors, no matter how much wants to change, following the policy is legality. Students prefer to involve into university; however, results-oriented told the reality is that no matter how much students involved into university, the level of political participation is low, only can farfetched sound university involvement can make the university better without the impact on political participation.

As to the factors of major and university identity in university environment group, the results are similar as previous study (G. \& Olsen, 2011; Schmiedel \& Recker, 2014; H. C. Yu, Lewis-Charp, \& Gambone, 2010), which means that the Major and University Identity has the positive relation to and impact on political participation.

University contains different majors in order to foster different professional talents who master both academic knowledge and right value-orientation. Students integrate with other students who belong to different majors, and in the process of integration, the individual is not only acquainted with different major students in the same university but also promotes a harmonious university environment formulation. Students support that there is no distance between different major students in political participation behaviors because the proponents acknowledge that the individual behavior keeping in similar pace in politics. Consequently, it is a normal result which was found in this research.

University identity is students' belongings in the university, the students are proud of the university, who prefer to change better in order to improve imaging of the university, even not allow others to slander university. The moral and righteous change is to safeguard the university imagine in the society and work for a better future of the university. The approval of the university influences the students' behavior; hence, it is no hesitation that university involvement has an impact and definite relation to political participation.

\section{Conclusion}

Political skill is "the ability to effectively understand others and to use such knowledge to influence others to act in ways that enhance ones' personal and university's objectives" (Ahearn, Ferris, Hochwarter, Douglas, \& Ammeter, 2004; Bentley et al., 2015); and the results in this research verify this statement by coincidence. Political value cognitive ability as core and critical ability in this study is the most important influential factor and displays negative relation to political participation because this kind of competence internally instructs students to clarify the reality and evaluate the outcome in the process of participatory politics foundationally.

By grasping the essence of political participation, it is no wonder that students' political value cognitive capability tends negative relation to political participation. Political efficacy refers to the ability in judging and understanding politics and then provides feedback under the political system requirements. Students are the great intellectuals with right political perception and political judgment ability should be affirmed. Therefore, the high political efficacy students have, the more strong relationship to political participation tends to. Leadership as a kind of the political skill, not only achieves to self-request to display ability, but also influence others to participate in politics, and in final to affect the whole level of political participation. Above that, competence as significant group elements in influential factors illustrates the close connection to political participation.

It is a new finding that there is no relation between political education and political participation, which indicates that denying the function of political education on political education appears in this research. The reasons can be traced to as follows: first is the distance between the content and reality, because educational context services for the authority and participatory reality is the limited influence; second reason can be attributed to the paradox between the subjective will and scramming method of teaching, even if students do not actively accept political education in the form of ITPC; the lack of personality and academic charm can be taken account into the third reason, the educators are short of charisma to influence indirectly students accept the education and further participatory behaviors.

University experience as a kind of political practice helps students recognize political reality as well as is a test method to examine the effectiveness of political participation; therefore, university experience plays a decisive role in students' political participation in university.

In the university environment group contains major integrated, university identity and university involvement. Major and university identity help students better engage in politics because individuals not only acknowledge the difference among a variety of majors and keep similar pace in participatory politics but also identify university profoundly and prefer to change oneself to make an attractive and harmonious university environment which salutary for students study, live and participate into politics. On the other hand, university involvement 
neither has relationship nor effect to political participation, because students would like to involve into university environment or life comfortably, by classifying the essence of political participation and calculating the benefits and cost and input low into participation. Therefore, university involvement is an intellectual element, compared to the relationship to the political involvement. It is no wonder that the influence and relationship of university involvement do not connect to the political involvement.

To sum up, political competence in this study is the most important for students' political participation in public universities of Hebei province, China. In order to improve students' participatory level, enhancing capability of students is a necessary way. Political education has neither effect nor relationship to political participation which is different from the previous study, whereas university identity, experience, major integrated undertake directly function on political participation; hence, it is best to focus on related elements which influence political participation without ignoring political education yet.

\section{References}

Ahearn, K. K., Ferris, G. R., Hochwarter, W. A., Douglas, C., \& Ammeter, A. P. (2004). Leader political skill and team performance. Journal of Management, 30(3), 309-327. http://dx.doi.org/10.1016/j.jm.2003.01.004

Bentley, J. R., Breland, J. W., Xu, N., Campion, E. D., \& Treadway, D. C. (2015). The political skill and will of expatriates in acculturating to the politics of an organization in a new culture. International Journal of Intercultural Relations, 49, 343-353. https://doi.org/10.1016/j.ijintrel.2015.06.002

Bolkan, S., \& Goodboy, A. K. (2009). Transformational leadership in the classroom: Fostering student learning, student participation, and teacher credibility. Journal of Instructional Psychology, 36(4), 296-306. https://doi.org/10.1080/08934215.2010.511399

Chan, A. L., \& Nesbitt-Larking, P. (1995). Critical citizenship and civil society in contemporary China. Canadian Journal of Political Science, 28(2), 293-309. https://doi.org/10.1017/S0008423900018850

DeSouza, P. R. (1986). Leadership, participation, and democratic theory. University of Sussex.

Dugan, J. P., Bohle, C. W., Gebhardt, M., Hofert, M., Wilk, E., \& Cooney, M. A. (2011). Influences of leadership program participation $\mathrm{n}$ students' capacities for socially responsible leadership. Journal of Student Affairs Research and Practice, 48(1), 65-84. https://doi.org/10.2202/1949-6605.6206

Eccles, J. S., \& Allan, W. (2002). Motivational beliefs, values, and goals. Annu. Rev. Psychol, 53, 109-32. https://doi.org/10.1146/annurev.psych.53.100901.135153

Eckstein, K., Noack, P., \& Gniewosz, B. (2013). Predictors of intentions to participate in politics and actual political behaviors in young adulthood. International Journal of Behavioral Development, 37(5), 428-435. https://doi.org/10.1177/0165025413486419

Fang, N. (2011). Annual report on political participation in China (2011). Beijing: Social Sciences Academic Press (CHINA).

Gallego, A., \& Oberski, D. (2012b). Personality and political participation: The mediation hypothesis. Political Behavior, 34(3), 425-451. https://doi.org/10.1007/s11109-011-9168-7

Gao, C. (2010). An investigation of contemporary college students' political participation-- A case study in some universities of Wuhan. Wuhan University of Technology(Social Science Edition), 23(2), 282-285.

Gao, W. (2008). The evolution of political participation patterns and social politics transformation. Tianjin Social Science, (2), 58-62.

Gao, W. (2009). Factor analysis on undergraduates' political participation in China. Journal of China Youth College for Political Sciences, (2), 23-29.

Gerber, A. S., Huber, G. A., Doherty, D., Dowling, C. M., Raso, C., \& Ha, S. E. (2011). Personality traits and participation in political processes. The Journal of Politics, 73(3), 692-706. https://doi.org/10.1017/S0022381611000399

G., M. J., \& Olsen, J. P. (2011). The new institutionalism: Organizational factors in political life. The American Political Science Review, 78(3), 734-749.

Hu, R. (2015). Chinese people's political efficacy, political participation and police trust. Sociological Study, (1), 76-96.

Kam, C. D., \& Palmer, C. L. (2011). Rejoinder: Reinvestigating the causal relationship between higher education and political participation. The Journal of Politics, 73(3), 659-663. 
https://doi.org/10.1017/S0022381611000363

Langton, K. P. (1969). Political socialization. New York: Oxford University Press.

Leighley, J. E. (1995). Attitudes, opportunities and incentives: A field essay on political participation. Political Research Quarterly, 48(1), 181-209. https://doi.org/10.1177/106591299504800111

Lu, J., \& Shi, T. (2015). The battle of ideas and discourses before democratic transition: Different democratic conceptions in authoritarian China. International Political Science Review, 36(1), 20-41. https://doi.org/10.1177/0192512114551304

Macpherson, C. B. (1977). The life and times of liberal democracy (1st ed.). Oxford: Oxford University Press.

Margetts, H. Z., John, P., Hale, S. A., \& Reissfelder, S. (2015). Leadership without leaders? Starters and followers in online collective action. Political Studies, 63(2), 278-299. https://doi.org/10.1111/1467-9248.12075

Mayer, A. K. (2011). Does education increase political participation? The Journal of Politics, 73(3), 633-645. https://doi.org/10.1017/S002238161100034X

Mezey, S. G. (1975). Political socialization and participation among university students in Thailand. Asian Survey, 15(6), 499-509. https://doi.org/10.2307/2643262

Ministry of Education of PRC. (2015, October 14). Opinions on Further Strengthening and Improving Ideological and Political Education for College Students. Xinhua Digest, pp. 1-4. Retrieved from http://old.moe.gov.cn/publicfiles/business/htmlfiles/moe/moe_1408/200703/20566.html

Montoya, L. J., Fanta-Hardy, C., \& Garcia, S. (2000). Latina politics: Gender, participation, and leadership. Political Science and Politics, 33(3), 555-561. https://doi.org/10.1017/S1049096500061564

Palmer, J. Q. (2014). A quasi-experimental study of changes in self-awareness and authentic leadership after participation in a volunteer event. Northcentral University.

Pateman, C. (1970). Participation and democratic theory. Cambridge University Press (1st ed.). London; New york; Melbourne: Cambridge University Press. https://doi.org/10.1017/CBO9780511720444

Pateman, C. (1986). Social choice or democracy? A comment on Coleman and Ferejohn. Chicago Journals, 97(1), 39-46. https://doi.org/10.1086/292816

Pateman, C. (2012). Participatory democracy revisited. Perspectives on Politics, 10(01), 7-19. https://doi.org/10.1017/S1537592711004877

Pattie, C., Seyd, P., \& Whiteley, P. (2003). Citizenship and Civic Engagement: Attitudes and Behaviour in Britain. Political Studies, 51(3), 443-468. https://doi.org/10.1111/1467-9248.00435

Pye, L. W., \& Verba, S. (1965). Political Culture and Political Development (1st ed.). Princeton: Princeton University Press. https://doi.org/10.1515/9781400875320

Schmiedel, T., \& Recker, J. (2014). Development and validation of an instrument to measure organizational cultures' support of business process management. Information \& Management, 51(1), 43-56. https://doi.org/10.1016/j.im.2013.08.005

Shen, J., Lei, W., \& Zhou, S. (2006). Problems in political participation by university students and measures for its important. Journal of Southwest Agricultural Universities(Social Science Edition), 4(2), 238-242.

Shi, T. (1997). Political participation in Beijing. Cambridge: Harvard University Press.

Syal, R. (2012). What are the effects of educational mobility on political interest and participation in the Indian electorate? Asian Survey, 52(2), 423-439. https://doi.org/10.1525/as.2012.52.2.423

Taber, C. S., \& Lodge, M. (2006). Motivated skepticism in the evaluation of political beliefs. American Journal of Political Science, 50(3), 755-769. https://doi.org/10.1111/j.1540-5907.2006.00214.x

Tao, D., \& Chen, M. (1998). Political participation in contemporary China. Hangzhou: Zhejiang People's Publishing House.

Thomas, R., Whybrow, K., \& Scharber, C. (2012). A conceptual exploration of participation. Section I: Introduction and early perspectives. Educational Philosophy and Theory, 44(6), 594-613. https://doi.org/10.1111/j.1469-5812.2010.00731.x

Vecchione, M., \& Caprara, G. V. (2009). Personality determinants of political participation: The contribution of traits and self-efficacy beliefs. Personality and Individual Differences, 46(4), 487-492. 
https://doi.org/10.1016/j.paid.2008.11.021

Verba, S., Schlozman, K. L., Brady, H. E., \& Nie, N. H. (1993b). Race, ethnicity and political resources: Participation in the United States. British Journal of Political Science, 23(4), 453-497. https://doi.org/10.1017/S0007123400006694

Wang, P. (2006). Foundations of politics. Beijing: Peking University Press.

Weare, C., Lichterman, P., \& Esparza, N. (2014). Collaboration and culture: Organizational culture and the dynamics of collaborative policy networks. Policy Studies Journal, 42(4), 590-619. https://doi.org/10.1111/psj.12077

Wheeler, A. R., Shanine, K. K., Leon, M. R., \& Whitman, M. V. (2014). Student-recruited samples in organizational research: A review, analysis, and guidelines for future research. Journal of Occupational and Organizational Psychology, 87(1), 1-26. https://doi.org/10.1111/joop.12042

Xing, J. (2008). Problems into some Chinese college students indifference to participate in current politics. Journal of Fujian University of Technology, 6(2), 117-122.

Xiong, G. (2015). Political efficacy: The process of standard research and empirical research. Study \& Exploration, 245(12), 41-47.

$\mathrm{Xu}, \mathrm{H}$. (2006). A research on the countermeasure of university student's political participation. Theory Monthly, (9), 177-179.

Yang, G. (2016). Still a century of Chinese model? Exploring dimensions of democratic centralism. Chinese Political Science Review, 1(1), 171-189. https://doi.org/10.1007/s41111-016-0005-3

Yuan, Z. (2011). On the dimensions of the participatory democracy. Journal of Xiamen University (Art \& Social Sciences), 205(3), 103-109.

Yu, H. C., Lewis-Charp, H. K., \& Gambone, M. A. (2010). Evaluating youth leadership development through civic activism. In K. M. Hannum, J. W. Martineau, \& C. Reinelt (Eds.), The Handbook of Leadership Development Evaluation (pp. 377-402). San Francisco: John Wiley \& Sons Ltd.

Zhang, H., \& Wang, M. (2011). Comparison between political participation for university students in reality and on the Internet in contemporary China: An empirical study on 336 university students in Nanjing. Nanjing Journal of Social Science, (9), 75-81.

Zhao, Z., \& Tang, X. (2008). Undergraduates' political participation--An analysis of five Nanjing universities. Educational Research and Experiment, (6), 37-41.

Zheng, H. (2012a). Participatory democracy and consultative democracy. Journal of Huazhong Normal University (Humanities and Social Sciences), 51(6), 17-26.

Zheng, L., \& Zhu, Z. (2013). Does education promote voting in China's grassroots democratic election? Evidence from CGSS 2006. Peking University Education Review, 11(2), 165-185.

\section{Copyrights}

Copyright for this article is retained by the author(s), with first publication rights granted to the journal.

This is an open-access article distributed under the terms and conditions of the Creative Commons Attribution license (http://creativecommons.org/licenses/by/4.0/). 